HID 44 (2017)

\title{
LA IDENTIDAD DEL PAISAJE: LA HUERTA ANDALUSÍ Y CASTELLANA DE MURCIA EN EL SIGLO XIII
}

THE IDENTITY OF A LANDSCAPE: ANDALUSI AND CASTILIAN

ORCHARDS AND GARDENS IN MURCIA IN THE $13^{\mathrm{TH}}$ CENTURY

\author{
MarÍA MarTíNEZ MarTÍNEZ \\ UNIVERSIDAD DE MURCIA \\ mariamar@um.es
}

RESUMEN: Reconstrucción del paisaje del regadío de Murcia en el siglo XIII, centuria en la que converge el legado hidráulico andalusí trasvasado al nuevo dominio castellano. La interpretación de textos árabes y castellanos compilados junto a algunos testimonios arqueológicos permite analizar la evolución de un paisaje natural milenario de agua y tierra a un paisaje humanizado por la sociedad islámica a partir del siglo IX con la fundación de Madinat Mursiya. Este desarrollado legado paisajístico de la huerta mursí, perdurable en la antroponimia y topominia, comenzaba no obstante a transformarse en poder de la sociedad cristiana en las décadas finales del siglo XIII.

Palabras Clave: Paisaje; Regadío; Siglo XIII; Al-Ándalus; Murcia; Castilla; Toponimia.

ABSTRACT: This article studies the reconstruction of the landscape of the irrigated land of Murcia in the $13^{\text {th }}$ century, at the time when it came under the dominion of Castile. The interpretation of Arabic and Castilian texts, together with archaeological testimonies, allows us to analyse how an ancient natural landscape of water and land had been transformed by the Muslims with the foundation of Madinat Mursiya in the $9^{\text {th }}$ century. This legacy of a cultivated landscape of orchards and gardens began to change, however, with the arrival of the Christians during the final decades of the $13^{\text {th }}$ century. Personal names and place names, on the other hand, did not change in the same way.

KEYwORDS: Landscape; Irrigation; $13^{\text {th }}$ Century; Al Andalus; Murcia; Castile; Place names. 


\section{INTRODUCCIÓN}

El paisaje es un factor de identificación de las culturas, las sociedades y los individuos en todo tiempo y lugar. La visualización de un paisaje determinado nos identifica, nos sugiere o remonta a sentimientos, emociones y vivencias porque es un paisaje real, presente o evocador, o puede que también imaginado o recordado de forma literaria, porque en cualquier caso ha formado o forma parte de nuestra vida o la de nuestros antepasados. En la recuperación del paisaje y de su memoria como sujeto-objeto colectivo de la identidad histórica, la persona o investigador interactúa con él en la construcción o reconstrucción de paisajes histórico-culturales, perdidos o transformados por la acción del hombre y del tiempo. Pero, aunque un determinado paisaje nos identifique -bien porque lo hayamos vivido e interiorizado, bien porque nos recuerde emociones o sentimientos- el estudioso debe interpretarlo desde un lenguaje visual - existen "paisajes fosilizados" apenas modificados por la evolución histórica- o, como en este estudio, mediante los testimonios que posibiliten analizar su evolución histórica y descifrar algunos de sus códigos. Esta es ahora nuestra propuesta: la construcción de una identidad social a través de un paisaje histórico-cultural, el del regadío medieval de Murcia, que sentimos como nuestro y cercano, aunque sea un paisaje muy transformado que hasta los años setenta del siglo XX se fundía con el de la ciudad.

Se va tratar de recuperar siquiera la esencia histórica del paisaje del regadío medieval de Murcia, tanto andalusí como castellano, a través de la lectura e interpretación de los textos árabes, los documentos conservados para el siglo XIII, especialmente el Libro de Repartimiento, los publicados en la colección de documentos para la Historia de Murcia y los exhumados en las investigaciones realizadas $^{1}$. Unas fuentes escritas conservadas que son muy valiosas para rememorar el paisaje de la huerta mursí, cuando, en ese siglo bifronte tan fundamental que fue el siglo XIII, el gran legado paisajístico islámico pasaba a dominio castellano. Con la relectura de los textos árabes y castellanos se lleva a cabo una labor de "arqueología del paisaje" a través de las fuentes escritas y los escasos testimonios arqueológicos para constatar desde el presente las características y transformaciones del regadío andalusí en la capital de nuestra región durante el gran cambio cultural que desde mediados del siglo XIII la integraba en Castilla y, sin solución de continuidad, en Europa, en la civilización occidental cristiana. Resulta muy abundante la bibliografía referida al estudio del paisaje hidráulico -o los espacios irrigados- que desde diversas perspectivas de análisis contiene la historiografía medieval española, que he relacionado en otros trabajos anteriores, si bien resulta oportuno recordar por el enfoque de cambio cultural y paisajístico que se ofrece ahora, los de Trillo, Glick y Malpica ${ }^{2}$, pues inciden en los cambios que tras la conquista cristiana se operan sobre las tierras andalusíes del dominio islámico.

1. Torres Fontes 1969, 1977, 1980, 1991, 2008.

2. Trillo 2003; Glick 2007, pp. 101-131; Malpica 2014, pp. 33-57. 
¿Cuándo se humaniza ese paisaje fluvial? ¿Desde cuándo tiene historicidad el asentamiento de gentes en la llanura aluvial murciana? ¿Y por qué y para qué se establecen en él? ¿Cómo fue el paisaje que habitaron las sociedades andalusí y cristiana convergentes en el siglo XIII?

Respuestas complejas que la información de los textos escritos, hallazgos arqueológicos y estudios filológicos del paisaje pueden concretar o aclarar, y que en este estudio se centrarán en esa centuria que engarza el fin del dominio islámico y el comienzo del castellano. Para ello, se aprovechan los restos escritos que reflejan la imagen veraz de un paisaje aún hoy reconocible en fragmentos y se interpretan desde el lenguaje encerrado en los documentos, que también hoy perdura. Con el estudio del paisaje se recupera una doble identidad: primero, la científica que nos liga al él, porque al recuperarlo lo comprendemos mejor y lo hacemos aún más nuestro; $y$ otra, porque como sujeto-objeto reconstruido nos reafirma en una identidad histórica forjada por nuestros antepasados a lo largo del tiempo.

\section{El PAISAJE NATURAL}

Cualquier paisaje parte de elementos naturales que cohesionan las formas de vida de quienes lo habitan y lo transforman. El río Segura fue el condicionante de la vida y el paisaje murcianos: creador del espacio urbano y del regadío. Y sobre ese inicial espacio fluvial que fue habitado a lo largo de los siglos se delimitarían las divisiones políticas o territoriales que conforman los mapas y fronteras geopolíticas en cada época: por ejemplo, la huerta de Orihuela estuvo integrada en la cora de Tudmir y en el reino de Murcia hasta 1304, cuando pasó a ser la frontera meridional del reino de Valencia en la Corona de Aragón. El espacio geográfico es pues la base donde la sociedad forja su identidad política, social y cultural. El marco natural donde se enclavaba la "huerta de Murcia" es un paisaje mediterráneo de agua y tierra cuyo artífice fue el río Segura a su paso por la ciudad, único con aguas permanentes en los $10.000 \mathrm{~km}^{2}$ que ocupa la actual Región. Un marco idóneo en el fondo de la depresión del Segura, cuyos rasgos fueron analizados por $\mathrm{Calvo}^{3}$, que ofrecía agua, suelo y temperaturas beneficiosas para aprovechamiento agrícola, si bien el área huertana se enfrentará a elementos negativos (aridez y crecidas) que sólo el continuo trabajo del hombre fue superando. El regadío murciano, extendido entre Alcantarilla y Orihuela, se extiende a lo largo de unos $30 \mathrm{~km}$ y obtuvo ciertos rasgos originales en el conjunto de las huertas levantinas.

La huerta de Murcia es una llanura de inundación configurada por la confluencia de los ríos Segura y su afluente el Sangonera o Guadalentín, flanqueada paralelamente por rebordes montañosos de escasa altura, a excepción de la sierra de Carrascoy que sobrepasa los 1.000 metros. Los cauces abandonados por ambos ríos se utilizaron para construir acequias de riego o, sencillamente, ponerlos en cultivo, aprovechando las crecidas y la fertilidad de los aluviones sedimentados en el valle

3. Calvo García-Tornel 1982, pp 19 y ss.; Hérin 1980. 
fluvial con materiales predominantemente arcillosos y arenoso-limosos que, como estos últimos, formaron suelos fértiles en ambas márgenes del río. Por el contrario, otros suelos pocos profundos y cenagosos impedían el drenaje en el sector norte y sur de la huerta, hacia Orihuela en la vega baja. Esta dificultad de drenaje de la vega junto a las temidas inundaciones equinocciales fue el factor fundamental por el que las culturas preislámicas no se asentaron sobre la llanura aluvial sino en la periferia, en los rebordes montañosos de cabezos y raigueros, a cierta altura, donde se situaba el límite del llano de inundación. La escasa profundidad del nivel freático, muy próximo a la superficie de la huerta en general, retiene el agua y dificulta en muchos sectores el drenaje o avenamiento de las tierras además de favorecer las inundaciones. El clima mediterráneo (sequías estivales y precipitaciones equinocciales) acentúa en la huerta de Murcia algunos rasgos que definen su peculiaridad (acusada humedad atmosférica, "continentalidad" o contrastes entre temperaturas diurnas y nocturnas, escasez e irregularidad de las precipitaciones, alto índice de aridez y evapotranspiración, etcétera).

Sin embargo, los musulmanes asentados desde el siglo IX en la depresión fluvial transformarían el antiguo campo espartario en una fértil huerta con un policultivo intenso gracias al desarrollo de un bien organizado sistema hidráulico. Junto al regadío, el extenso secano del campo se convertiría en el paisaje ganadero por excelencia, que completaba el espacio agrícola de riego. En suma, agua y suelo conforman la huerta nacida de los caudales y materiales aportados por el río Segura, aunque de este provendrán también sus temidas crecidas o sequías. Y será este paisaje natural del agua fluvial, intervenido por el hombre durante siglos, el que gestará una de las señas de identidad más reconocibles de la sociedad murciana: la huerta y la gente que la ha habitado, el huertano, hoy casi una especie en extinción. Porque la permanente actividad humana a lo largo del proceso histórico ha ido degradando el medio natural y los perceptibles cambios del ecosistema, acelerados desde mediados del siglo XIX hasta la actualidad.

\section{El PAISAJE HUMANIZADO}

El paisaje natural experimentó a lo largo de los siglos la intervención de las sociedades que lo poblaron: ¿Pero, desde cuándo hay constancia de gentes habitando este espacio?

Sin remontarnos a tiempos protohistóricos o prerromanos, y comenzado por la romanización, esta, como es sabido, tuvo mayor intensidad en la zona costera de Murcia -incluido el campo de Cartagena- para irradiar más tardíamente hacia el interior mediante asentamientos rurales en forma de villas o grandes propiedades que formaban poblados agrarios de diversa importancia. En el poblamiento tardorromano-visigótico murciano destacan el existente en torno a la actual Alberca, donde se han conservado restos monumentales de un martiryum del siglo IV, o el de Algezares con restos de una basílica del siglo VI, donde algunos situaron la antigua Ello, la ciudad destruida para fundar Madinat Mursiya en el siglo IX. 
Durante la época tardo-antigua las vegas fluviales del Segura, eje articulador del espacio, comenzaban a poblarse, siquiera débilmente. No obstante, parece meridianamente plausible que el regadío romano no fue generalizado, sino más bien limitado su desarrollo para algunos cultivos como la vid, lo que implicaría la formación acaso de pequeños sistemas hidráulicos. Sin embargo, para el sistema del regadío murciano su origen romano actualmente queda invalidado por recientes estudios y algunas excepcionales excavaciones arqueológicas, que confirman lo que se mantuvo en combinación con las fuentes escritas ${ }^{4}$. La captación de agua, ese secreto de la vida calificada como "oro azul", y la aplicación generalizada de las técnicas de riego durante el dominio islámico desarrollaron una extensa colonización de la vega media mursí. Grupos de gentes diversas preislámicas (romanas, visigodas), islámicas y cristianas aportaron a lo largo de las centurias su trabajo para la transformación de este paisaje fluvial.

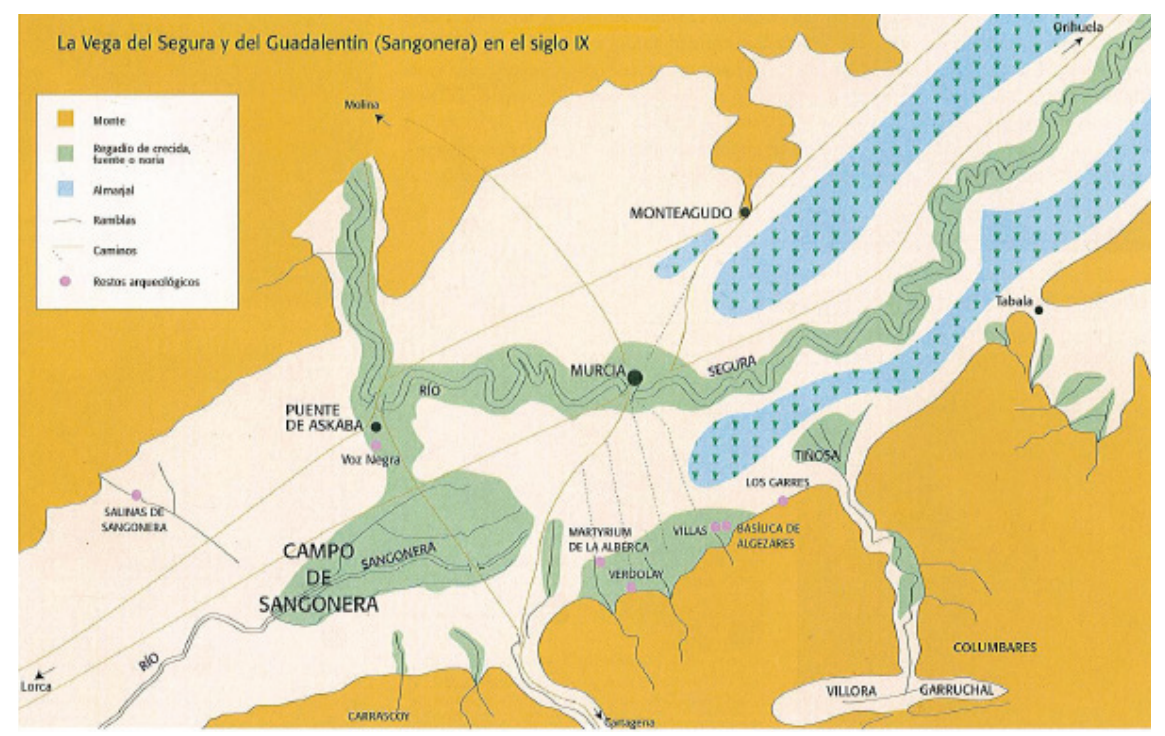

Fig. 1: Fuente, Atlas histórico ilustrado de la Región de Murcia y su antiguo Reino, Murcia, 2006, p. 85.

Aun teniendo en cuenta la existencia de villas o grandes explotaciones agrarias de época romana en el regadío murciano, la posterior ruralización e inestable etapa visigoda trasladó el poblamiento del valle medio hacia un poblamiento más seguro en altura (en torno a los husun de Monteagudo y Verdolay), lo que minimizaría la explotación de la huerta murciana ya que solo comenzaría a colonizarse con continuidad a lo largo de toda la etapa medieval, andalusí y castellana.

4. Martínez Martínez 2013a, p. 31. 


\subsection{Formación y desarrollo del paisaje hidráulico mursí}

Tras la ruralización de la vida, consecuencia del fin de mundo romano y la instalación de visigodos en el sureste peninsular, fue la mayoritaria sociedad islámica árabe y bereber quien de manera continuada colonizaba el valle medio de Segura y organizaba - a partir del polo de atracción urbana de Madinat Mursiya- el regadío murciano en varias fases para la permanencia y desarrollo de las comunidades campesinas organizadas en torno a la medina ${ }^{5}$.

La presencia del islám en la Región de Murcia se remonta al pacto de Tudmir (713), y de manera sobresaliente en el valle medio del Segura a partir de la fundación en el año 825 de Madinat Mursiya, cuando la colonización y explotación del regadío iniciaba su génesis dentro de la planificación de un sistema hidráulico que fue organizándose desde entonces. Quienes se asentaron desde el siglo IX en Murcia y su entorno rural utilizaron el agua fluvial para riego de las tierras y como fuente de energía, y crearon y desarrollaron un sistema hidráulico aún vigente en su estructura originaria.

El asentamiento militar del yund de Egipto y de otros grupos clánicos para el control del territorio en los valles del Segura y del Guadalentín (Sangonera) durante el siglo VIII fue origen de conflictos internos, que están en la base de la fundación de Mursiy $a^{6}$-en un meandro del río- como nueva capital de la qura de Tudmir, necesitada del sostén de una economía agrícola explotada por una sociedad rural que colonizaba intensivamente el territorio de la llanura fluvial segureña alrededor de la medina.

Es sabido que el islám nació en un medio árido (Arabia) y en su expansión a Occidente los musulmanes desarrollaron, desde el sincretismo romano, oriental y bereber, técnicas que construyeron un paisaje de agua, a modo de oasis, que otorgó identidad propia a las afamadas huertas de Sharq al-Andalus. Las posibilidades de suelo y agua en la vega media del Segura aseguraron el asentamiento originario de comunidades campesinas arabo-bereberes, quienes cohesionadas por solidaridades clánico-tribales -en proceso de debilitamiento tras la conquista y configuración del estado Omeya- organizaron las alquerías donde habitaron y trabajaron a través de una gestión racional del agua que se ligaba a la propiedad de la tierra, como establecía el derecho malequí imperante en Al-Ándalus. Asentamientos rurales que se comunicaban con la medina e internamente por caminos que vertebraban el regadío mursí. Un poblamiento rural y periurbano irrigado y disperso en alquerías, rahales (que compartían riego y explotaciones de secano) y reales o huertos en el entorno de

5. Vid. además de los clásicos e insoslayables estudios de la huerta realizados en el siglo XIX por Mancha 1836 y Belando y Menéndez 1887, algunos dedicados al estudio de la huerta andalusí por Torres Fontes 1991b; Calvo García-Tornel 1989; Calvo García-Tornel y Olivares 1967-1968; Manzano Martínez 1993, 1999a , 1999b; Pocklington 1990, 2013; Carmona González y Pocklington 2008; Martínez Martínez 2010, 2013a, 2015.

6. Hay quienes apuntan que la fundación de Mursiya no fue ex novo, sino que se situó sobre una villa o poblado agrario romano, lo que no invalida su creación como una medina (fisonomía urbana y centro administrativo, político y económico), sobre un lugar del valle que estaba parcial o escasamente colonizado. 
la medina (cercados y bien integrados en el sistema hidráulico) que fue definiendo el paisaje agrario del regadío mediterráneo y transformándolo con la introducción de nuevas especies y la implementación de cultivos tradicionales (cereales, vid y olivo). Frutales (naranja agria, pomelo, limón, plátano, sandía, dátiles, mango, cocotero, etcétera), nuevos cereales o variedades (arroz, trigo duro, sorgo, etcétera), caña de azúcar, fibras vegetales (algodón), verduras y hortalizas (espinaca, berenjena, etcétera) y especias se importaron desde Oriente y se cultivaron rápidamente adaptadas en al-Ándalus, si bien existen dudas historiográficas al respecto y el debate no ha concluido $^{7}$. Aun manteniendo esta duda referente a la introducción de algunos cultivos en al-Ándalus, la adaptación y aclimatación de nuevas especies en jardines y huertos y la explotación de tierras de cereal y viñas mezcladas con higueras caracterizaron el paisaje agrario mursí, según lo describió al-Idrisi en el siglo XII.

Otros muchos testimonios confirman la realidad de una fértil agricultura intensiva que, favorecida por las bondades del clima y la optimización de los recursos hídricos, practicaron y extendieron los andalusíes, tal como un anónimo autor árabe elogiaba para el regadío murciano: abundancia y calidad de trigo, cebada y fruta, acequias que recorren arboledas y huertos, numerosos molinos en las acequias y las riberas segureñas. Los textos redundan en la exquisitez y variedad de frutales (peras, granadas, membrillos, higos y uvas), en un frondoso paisaje de árboles, palmerales, nogales y morales, jardines y huertos (con variedad de arbolado, hortalizas y legumbres), remedo de la imagen del paraíso coránico ${ }^{8}$.

Considerado, como se ha expuesto, que el desarrollo del regadío murciano estuvo ligado a la fundación de Madinat Mursiya por Abdherramán II -y que este fue ampliándose durante diversas fases, que no excluyen discontinuidades internas, hasta mediados del siglo XIII, cuando fue heredado por la nueva sociedad cristiana-, el sistema hidráulico ha de articularse, necesariamente, con la gran transformación agrícola que el Islam trajo a la Península, que ha sido calificada, por contraste con la agricultura pre-árabe, como "revolución". Aun sin exagerar, la denominada "revolución verde" sí permitió que la agricultura de riego caracterizadora del mundo andalusí adaptase y desarrollase muchos y nuevos cultivos así como la superficie a ellos dedicada, en coexistencia con la tradicional agricultura de secano. Técnicas agrarias (rotación de cultivos) e hidráulicas diferenciadas (de captación y distribución para el aprovechamiento del agua) y formas de explotación de la tierra y reparto de la propiedad coadyuvaron en el aumento y variedad de la producción agraria ${ }^{9}$, fundamento económico de la sociedad islámica.

Técnicas hidráulicas y algunas nuevas especies introducidas por los musulmanes crearon la impronta paisajística del regadío mursí, cuya cota máxima de expansión se sitúa en el siglo XII. Y a partir de la derrota almohade en Las Navas, la apertura del valle del Guadalquivir a las futuras conquistas cristianas sobre alÁndalus y la inmigración musulmana hacia la taifa murciana de Ibn Hud contribuyeron a la plena colonización del valle y la expansión de la medina.

7. Eiroa Rodríguez 2011, p. 249.

8. Martínez Martínez 2015, pp. 58 y ss.

9. Eiroa Rodríguez 2011, p. 248; 2010a, 2010b. 
Paisaje mursí transformado e integrado en un sistema socio-económico de agua, tierra y población rural dispersa en las alquerías. Y debe advertirse que un sistema hidráulico se explica por y para la sociedad que lo organiza, desarrolla o adapta, lo que implica conocer en este caso las diferencias culturales entre la sociedad andalusí y la castellana: ahora bien, este mismo legado paisajístico utilizado por sociedades divergentes pudo mantenerse en esencia, pese al cambio social y de poblamiento y de las significativas transformaciones en las últimas centurias del medievo.

En 1495 el viajero alemán Jerónimo Münzer resumía así la impronta andalusí conservada en el paisaje murciano de finales del Medievo, donde agua-tierra y huerta-ciudad quedaron integradas:

La ciudad está enclavada en una bella planicie rodeada de montañas, como Milán, pasa por ella el río Segura, del que arrancan varias acequias que distribuyen el agua por todos sitios. Es tierra que produce mucho aceite, arroz, almendras, cereales, y los viveres van en ella muy baratos.

El decimonónico y tradicional debate acerca de los orígenes romanos o andalusíes del sistema hidráulico en algunas huertas levantinas está prácticamente superado. Abundemos que para la de Murcia (cuya extensión durante época andalusí fue progresiva desde el siglo X), sí resulta claro que no hubo continuidad entre la época romana y la islámica y, especialmente, como se infiere también de los resultados arqueológicos, el regadío preislámico se reduciría a pequeñas áreas de explotación que no estaban integradas en un organizado sistema hidráulico. La formación y desarrollo del regadío mursí se ha revalidado recientemente con la arqueología: así se demuestra en el sector central de la huerta de Murcia con la aparición de dos aceñas en la acequia de Churra la Vieja (derivada de la de Aljufía) y una tercera y un tablacho en la de Alfatego, más arcaduces de noria hallados en el yacimiento "Senda de Granada", datados en los siglos X-XI, es decir en la fase de génesis del regadío murciano, pero sin continuidad con los estratos romanos; y también, presumiblemente, con otras dos intervenciones arqueológicas efectuadas: la primera en el acueducto de la noria de Alcantarilla -que descarta su origen romano aunque no se pudo precisar con fiabilidad su datación-, y la segunda en el acueducto de los Arcos (Alcantarilla), que aun sin datar, sí informa de la prolongación de la red de riego en época andalusí desde la acequia-acueducto de Alquibla que continuaba por los de El Turbedal y La Dava ${ }^{10}$, existentes cuando llegaron los castellanos a mediados del siglo XIII. Y apuntalando el origen andalusí del regadío, resulta elocuente que en el Fuero Juzgo o antiguo código visigodo nada haga presuponer la existencia de un organizado y extenso sistema hidráulico, puesto que solamente incluye algunas referencias a la pesca fluvial, al robo del agua del río o a la rotura de pesqueras y $\operatorname{molinos}^{11}$.

10. García Blánquez y Cerdá Mondéjar 2007; López Campuzano 2002.

11. Perona 2002, pp. 345-346. 


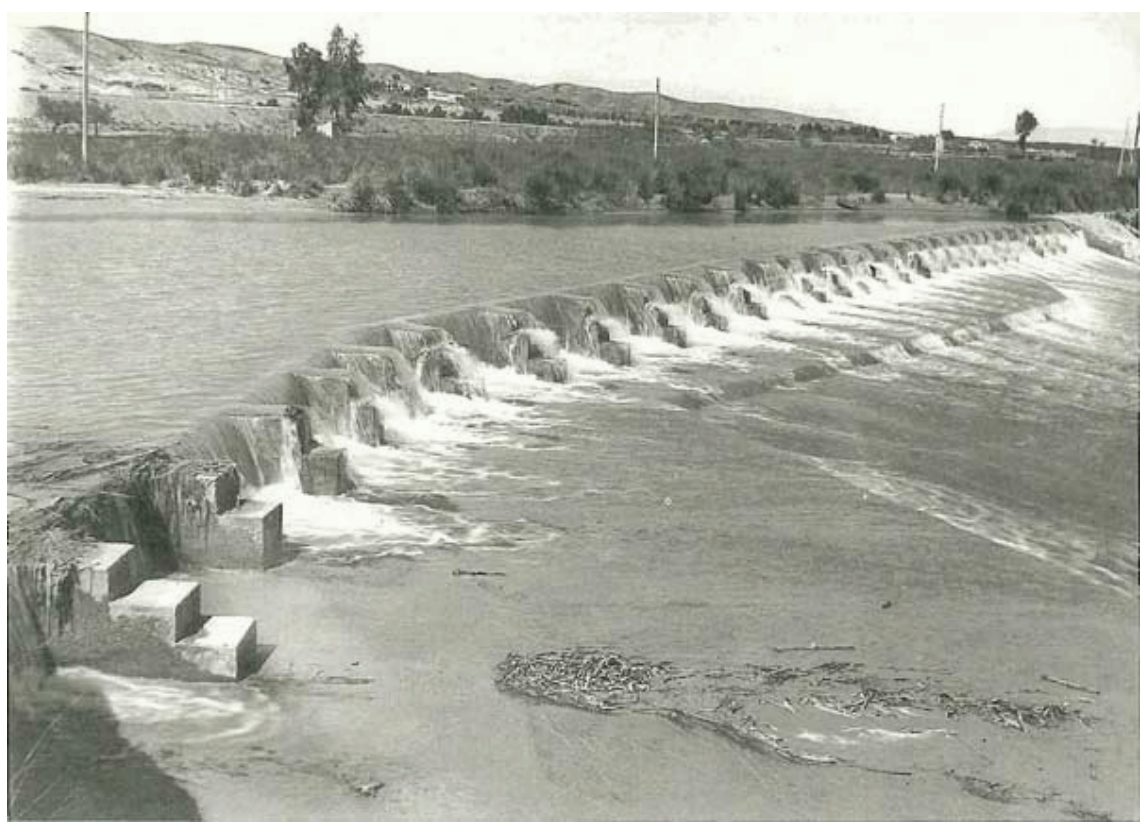

Fig. 2: Azud Mayor o Contraparada, origen del sistema del regadío medieval.

El desarrollo de la red hidráulica, base del sistema del regadío, comenzaría durante los siglos IX-X en la mitad septentrional, entre el Azud mayor ${ }^{12}$ y la medina a partir de una acequia mayor (seguramente la de Aljufía) ya existente, según señalaba al Udri, en el siglo XI:

El río de Tudmir posee norias que riegan las huertas de este territorio. El comienzo de la acequia que parte de este río esta en Qantara Askaba (Alcantarilla) y alcanza las propiedades de los habitantes de la ciudad de Mursiya hasta el límite de la alquería de Taws (Cox), que es una de las alquerías de la ciudad de Orihuela ${ }^{13}$.

Es el primer documento que describe hacia 1075 el sistema hidráulico murciano, visto directamente por el autor, y según parece solo existía entonces una acequia, posiblemente la del norte o Aljufía, pues planteaba menores obstáculos "al no tener que atravesar la desembocadura del Guadalentín, y al mismo tiempo facilitaría el abastecimiento de agua a la creciente ciudad de Murcia, construida sobre la ribera norte del Segura"14. Es lógica esta afirmación que se corrobora además con los únicos hallazgos arqueológicos datados en estos siglos (X-XI) en

12. Del ár. "sudd" = obstáculo o presa en un río o acequia, denominado mayor para indicar la importancia de la construcción desde la que se originaba el sistema hidráulico. Situado en las proximidades del actual Javalí, a unos siete km aguas arriba de la madina.

13. Torres-Fontes Suárez 1996, p. 332; Carmona González y Pocklington 2008, p. 49.

14. Carmona González y Pocklington 2008, p.149. 
el yacimiento de "Senda de Granada", y que señala que la construcción del azud mayor se había realizado con anterioridad (entre finales del siglo X y principios del XI) y, consiguientemente, en época romano-visigoda no existían ni la presa ni las acequias. La prolongación de la acequia de Aljufía así como la derivación de otras y la nueva construcción de la de Zaraíche extenderían el regadío aguas abajo por el cuadrante NE hasta los límites de Orihuela.

Un extenso regadío que se completaba con la construcción de una segunda acequia (la de Alquibla) para el riego de las tierras de la zona sur o margen derecha del río, por lo que en realidad la huerta mursí se configuraba a partir de dos sistemas hidráulicos complementarios, bien descritos por al-Hymyari (siglos XIV-XV) -que se fundamentaba en al Udri y otros autores-, que captaban las aguas del Segura en un punto común, en las proximidades de Qantarat Askaba (entre Alcantarilla y Javalí) del que partían dos canales subterráneos excavados en las vertientes de dos montañas paralelas para desviar las aguas a las tierras del sur y norte de la huerta. Se trataba en los primeros tramos de las acequias de túneles subterráneos con perforaciones o respiraderos (a modo de galerías con "lumbreras" o minas), cuyas respectivas longitudes aproximadas eran, respectivamente, de 1,3 km y $2,7 \mathrm{~km}$. Canalizaciones que -cortadas transversalmente mediante una presa (azud mayor) - continuaban a cielo abierto por las acequias mayores de Alquibla y Aljufía que regaban las zonas meridionales y norteñas de la huerta murciana a lo largo de un recorrido de $8,2 \mathrm{~km}$ hasta llegar a la medina, tal como se deduce de su texto:

Del río de Murcia sale, cerca de Qantarat Askaba, un canal que excavaron los antiguos en la montaña, que es una montaña de roca dura, la cual perforaron a lo largo de una milla más o menos. Este canal es el que riega la parte que se halla al sur de la ciudad. Enfrente de la mencionada conducción, excavaron en la montaña que hay paralela a la anterior otro túnel, de una longitud de unas dos millas, por el que hicieron discurrir un segundo canal, que es el que proporciona agua a la parte que se encuentra al norte de Murcia. Ambos canales tienen respiraderos practicados por encima, en la montaña. Disponen también de cauces que vierten al rio y que sirven para limpiar los túneles: para ello basta con abrirlos y dejar que descienda el agua arrastrando toda la suciedad alli acumulada. Todo el riego que proviene de Murcia se realiza a partir de esos dos canales, excepto el agua que se eleva mediante norias y aceñas. Entre el lugar donde paren ambos túneles y Murcia hay seis millas ${ }^{15}$.

Lo expuesto contradice lo que se ha mantenido tradicionalmente: que la incorporación al regadío del sector sur de la vega fue posterior al del norte, vinculada aquella a la construcción de la otra acequia mayor, elocuentemente denominada Alquibla (actual Barreras), y de donde también derivaban otros muchos cauces (Alfande, Dava, Turbedal, Alcantarilla, etcétera). Con ser la opción que la historiografía ha impulsado ${ }^{16}$, la lectura del fragmento de al-Hymyari, traducido por Pocklington, parecería indicar lo contrario, que el primer canal excavado por los

15. Ibid, pp. 150-151.

16. Martínez Martínez 2013a, pp. 30 y 84. 
antiguos correspondiera a la acequia mayor de Alquibla que regaba la zona sur de la huerta. A tenor de lo expuesto he replanteado la cuestión de la antigüedad de las dos acequias mayores, que merecería ser aclarada, ya que en la pionera traducción de Levi Provençal ${ }^{17}$, se indicaba lo contrario:

Del río de Murcia sale un canal cerca del puente llamado Kantara Askaba, y sigue un conducto abierto por los antiguos a través de la roca de la montaña, que han perforado a lo largo de una milla. Este canal riega el terreno al norte de Murcia. Ambos canales subterráneos están provistos de pozos de aireación, que comunican con la cresta de la montaña, y compuertas abiertas en dirección del río; abriéndolas, se pueden limitar los canales y arrastran con las aguas el lodo que se haya podido amontonar. Fuera de estos dos canales no se riega con el agua del río de Murcia, si no es por medio de ruedas elevatorias llamadas dawlab y saniya. Entre el punto en que nacen estos dos canales y Murcia hay seis millas.

Sin embargo, Pocklington, quien considera fiable a al-Hymyari, traduce, como se ha comentado, lo contrario: que la primera acequia construida fue la de Alquibla. No obstante, el autor, tras la inspección del terreno origen del sistema de riego, concluye que en la actualidad ninguna de las dos acequias tiene ningún tramo subterráneo, aunque hay, refiriéndose a la acequia del Aljufía:

un curioso túnel excavado en el cerro alargado que bordea la ribera derecha del río, a la altura del azud. El túnel penetra en la roca del cerro unos doscientos metros más arriba del azud, y desemboca enfrente del mismo; la sección del túnel es rectangular, midiendo aproximadamente $1 \mathrm{~m}$. de ancho por 1.70 de alto, y se observan aún algunos respiraderos; a la entrada la roca está socavada y blanqueada, aparentemente debido a la acción constante del agua; a la salida, el último trozo se ha perdido en las obras de excavación de un canal ancho a través de la cola de la peña, junto al azud para facilitar el paso de la acequia mayor de Alquibla (=Barreras). Hoy en día la desembocadura del túnel se encuentra a cuatro o cinco metros por encima del nivel del río...

La hipótesis que formula Pocklington, tras la inspección de estos restos, es que el Azud Mayor en época islámica se construyó más arriba de su ubicación actual, en la misma boca del túnel comentado, porque el río pasaba junto al mismo cerro, lo que obligaría a los constructores o bien a perforar el cerro, o bien a iniciar la acequia cientos de metros más abajo... Y referente al túnel de la Alquibla no han quedado restos; pero en cualquier caso opina que las medidas de los tramos subterráneos de las acequias precisadas por al-Hymyari fueron exageradas ${ }^{18}$. A mi entender y con la aportación de estos restos sigue sin clarificarse la antigüedad de las acequias, tan sólo, quizá, que la construcción de la Aljufía necesitase en principio de un mayor esfuerzo dado su mayor longitud subterránea ¿pero es suficiente para explicar su más tardía construcción? Por otra parte, ha sido en la zona norte donde

17. Cit. por Torres Fontes Suárez 1996, t. II, pp. 372-373.

18. Carmona González y Pocklington 2008, pp. 150-153. 
se han exhumado los únicos restos de la hidráulica mursí, y también que en entre los años 1269-1270 cuando se ampliaban los repartos en el regadío (pues ya se había repartido la mitad norte de la huerta) entre la nueva oleada de repobladores se repartían unas 10.000 tahúllas de tierra de la otra mitad de la huerta en la zona de allende de la acequia mayor de Alquibla-la configurada por el riego de las acequias de Alharilla, Alguazas, Alquibla Turbedal y Herrera-, lo que se correspondía con la denominada huerta nueva registrada en el pacto de Alcaraz de 1243, cuando se iniciaba el protectorado castellano y el vasallaje musulmán.

Información arqueológica y escrita que no parece dejar duda a que el inicio del sistema hidráulico andalusí comenzaba con el riego de la zona del noroeste del regadío. También la documentación bajomedieval castellana menciona como huerta vieja o cuerpo de la huerta (de origen andalusí) al espacio comprendido en la zona norte y sur desde el azud mayor hasta la ciudad, entre las acequias de Benétucer y Alfande. Zonas que en el NO y SE y aun sin distinguir la antigüedad de riego entre ambas, sí se diferenciaban de esa otra "huerta nueva" explotada en la periferia del regadío y en los sectores más bajos a ambos lados del río, desde la ciudad hasta las tierras colindantes con la huerta de Orihuela entre Monteagudo y Beniaján ${ }^{19}$.

Y continuando con la formación en fases del sistema hidráulico mursí, ha de tenerse en cuenta una noticia extraída de al-Udri y publicada recientemente por F. Franco $^{20}$, que informa del devastador terremoto que hacia $1048-1049$ se produjo en Murcia, Orihuela y las alquerías circundantes. Entre las graves consecuencias de estos seísmos continuados durante un año -que probablemente llegaron a alcanzar en algún momento los 7.5-8 grados en la escala Richter- se mencionan el derrumbamiento de casas, edificios altos, alminares de mezquitas y torres, castillos y fortalezas, a los que se sumaban los estragos producidos en la infraestructura hidráulica (presas, canales, acueductos, norias, molinos, etcétera); y además, según precisa el autor árabe, estos terremotos cambiaron el curso de las aguas subterráneas y la subida del nivel freático con la extensión y reaparición de almarjales y la derivada insalubridad de las aguas estancadas.

Pero lo que importa ahora para dilucidar la mayor o menor antigüedad de los dos sistemas hidráulicos formados por las acequias de Aljufía y Alquibla, es la relación de estos intensos seísmos con su reconstrucción-adaptación, que afectaría al azud mayor, y que, como expuso al-Udri, originaría el desencajonamiento de las aguas del río, lo que obligaría a establecer una modificación de su toma y canalización, bien construyendo o reconstruyendo una segunda acequia (posiblemente la Alquibla) o/y reencauzando la Aljufía desde una toma situada en un nivel más bajo. Hecho que podría clarificar la duda planteada respecto a la antigüedad de ambas acequias mayores en el texto de al-Hymyari, pues -aunque el autor pudo confundir datos porque su información no era de primera mano- sí explicaría que esta reestructuración en la cabecera de la acequia mayor de Aljufía se confundiese con la creación nueva de dicha acequia. De todas formas, se evidenciaría que des-

19. Martínez Carrillo 1997, p. 66; Martínez Martínez 2013a, p. 47.

20. Franco Sánchez 2014, p. 166. 
de mediados del siglo XI, tras el terremoto, el sistema hidráulico se reestructuraría completamente en una segunda fase a partir del último cuarto del siglo XII, y así lo encontrarían los castellanos a mediados del siglo XIII ${ }^{21}$.

En suma, primero se extraía directamente el agua del río mediante la excavación de la dura roca, seguidamente se embalsaba y se canalizaba por los dos cauces de aguas vivas o acequias para finalmente evacuar al río las aguas muertas o sobrantes del riego por los azarbes o canales de drenaje. Extracción, canalización, derivación, distribución y drenaje cierran el complejo círculo formado por una jerárquica estructura de riego y avenamiento articulada por acequias mayores, menores, brazales e hijuelas y azarbes, landronas o meranchos, azarbetas y escorredores correspondientes a dos sistemas hidráulicos que se complementaban. Azudes o presas, norias, aceñas, embalses, canales de drenaje o azarbes y molinos fijos instalados en las acequias o las riberas del río completaban el paisaje hidráulico.

Este complejo y costoso sistema en continua reparación y exigencia de limpieza para su buen funcionamiento, se ha comparado con el circulatorio del cuerpo humano (arterias o acequias y venas o azarbes): porque poco provechoso sería el riego de la tierra si luego no se pudiese drenar el agua sobrante al quedar inundada la misma, lo que, siguiendo con la comparación antropomórfica, y según me comenta Juan Tovar del Consejo de Hombres Buenos de Murcia, sería como si una persona bebiese agua pero luego no pudiese evacuarla mediante la micción.

$\mathrm{Y}$ cuando Castilla incorporaba el territorio murciano, el sistema de riego andalusí estaba perfectamente establecido con unas complejas técnicas de reparto de agua que vinculaban proporcionalmente el caudal de agua que se distribuía a través de los partidores establecidos en el Azud Mayor para ser medido en tiempos de riego semanales, de siete días, en los que se fijaban los turnos de horario diurno y nocturno de los regantes según la superficie de tierra a regar que cada uno tenía ${ }^{22}$. Unas tierras predominantemente minifundistas, que coexistieron con otras propiedades de mayor extensión, como he probado para una minoría de musulmanas a quienes les fueron expropiadas tras el domino castellano ${ }^{23}$.

La gran superficie de tierra dedicada al regadío favoreció el cultivo predominante de trigo, cebada, frutales, lino, cáñamo y plantas aromáticas y de jardín, favorecido por una racional distribución del agua por turnos y complejas técnicas de avenamiento y drenaje. Y también el regadío andalusí se utilizaba para el pasto

21. Otra significativa reestructuración se efectuaría a mediados del siglo XV, tras la intensa riada de 1452: Martínez Carrillo 1997, pp. 66-71.

22. Menjot 2008, pp. 75-77; Martínez Martínez 2013a, pp. 51-52 y 58.

23. Estableciendo la correspondencia utilizada por los repartidores para asentar a los peones y caballeros cristianos, registrados en el Libro del Repartimiento de la segunda mitad del siglo XIII, de entre las 70 musulmanas registradas, la mayoría eran consideradas pequeñas y medianas propietarias pues tuvieron tierras valoradas económicamente entre una (o incluso menos) y cuatro alfabas, mientras que a partir de esta cifra solamente una minoría puede considerarse grandes propietarias, entre las que se registran estas siete: Atica, hija de Bubacar (11,5 alfabas), Aixa Haquen (14 alfabas), Fátima, hija de Odzmen Addehabia (8 alfabas), Fátima, hija de Abn Çaad Axalarqui (8 alfabas), Muhya, hija de Aben Mayçara (10 alfabas), Zohara Alfandadi (8 alfabas aunque compartidas con su hermano), la mujer de Ahmet Almexadad (19 alfabas junto con su marido): Martínez Martínez 2012, pp. 181-187. 
de todo tipo de ganado. Un sistema de regadío propulsado para desarrollar la agricultura intensiva en un medio semiárido como el murciano. Asimismo, el deterioro del sistema hidráulico conllevó la extensión de almarjales que caracterizaron el paisaje del regadío, exponente de la disminución del área agrícola tras el fracaso de la repoblación cristiana, a la que se enfrentó la política castellana bajomedieval para la explotación y desecación de estas tierras pantanosas ganadas por el agua, descritas en el Libro de la Caza de don Juan Manuel.

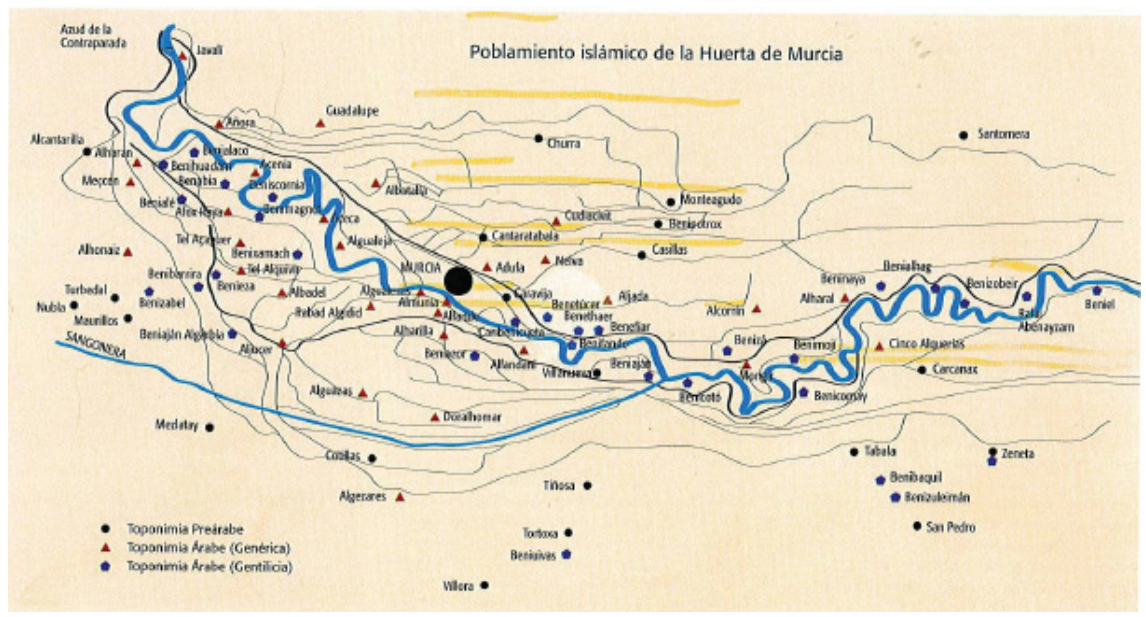

Fig. 3: Fuente, Atlas histórico ilustrado de la Región de Murcia y su antiguo Reino, Murcia, 2006, p. 90.

El incremento del área regada se ha calculado en torno a las 6.000 Ha. antes del dominio cristiano de mediados del siglo XIII, y se constituye como el paradigma andalusí de una agricultura intensiva que copaba la demanda de una población en crecimiento (unas 70.000 personas en el siglo XII) que, además, comercializaba sus excedentes. La transformación de la producción agraria para abastecer el consumo interno y el comercio fue posible por el desarrollo de la molinería hidráulica que se fijó sobre el paisaje del regadío: ruedas horizontales o rodeznos, verticales o norias y aceñas y molinos hidráulicos para el riego de las tierras y la molturación de grano, plantas tintóreas, prensado de olivas, obtención de papel, etcétera, explican el desarrollo económico andalusí.

El conocimiento de las técnicas hidráulicas aplicado al uso energético del agua fue fruto del sincretismo grecorromano y arabobereber, y se insertaba en al-Ándalus, convertido en la frontera de dos civilizaciones, islámica y cristiana, durante casi ocho siglos. La disponibilidad de agua y la organización del sistema hidráulico (presa, cubo, balsa y canales para abastecer la molinería, etcétera) impulsaron la capacidad y los rendimientos de estas poderosas máquinas registradas por los autores árabes para Mursiya. Algunos de los molinos documentados en las fuentes escritas árabes y cristianas inmediatas a la conquista del emirato hudí confirman 
su importancia, tanto en el espacio urbano - dentro y fuera de las murallas- periurbano y rural, en las riberas y cauce del río Segura, en acequias, ramblas, arroyos o cursos naturales. Una diversificada tipología molinar poblaba la vega mursí: molinos flotantes o de barcas en el tramo urbano del río, aceñas o molinos de rueda vertical, abundantes rodeznos o molinos de rueda horizontal, principalmente destinados para el aprovisionamiento alimentario de la sociedad urbana y campesina ${ }^{24}$.

También los excepcionales restos arqueológicos encontrados en la zona norte de la huerta andalusí, donde se originaba el sistema hidráulico, datan la existencia de aceñas de los siglos IX-X en la actual Senda de Granada, según se ha indicado. Mientras que en el río a su paso por la ciudad las ruedas molinares se instalaban sobre barcazas que podían moverse por el cauce en función de su caudal: se trataba de los molinos flotantes que alababa al-Idrisi, como los existentes en la medina de Zaragoza. Por el contrario, en las zonas con menor caudal de agua (como las de Sangonera y Tiñosa, regadas por crecida o alfait o con artilugios rudimentarios, procedente de las escorrentías de las ramblas y de las vertientes de los rebordes montañosos que rodeaban el regadío de la zona sur) se instalaron molinos estacionales, como el equipamiento de almazaras en Tiñosa o los establecidos en zonas de secano colindantes con el regadío, situados en el extenso Rahal Axarqui (en el extremo occidental de la huerta, cerca del término de Librilla), alimentados por el arroyo que salía de la acequia del molino y el agua de la rambla y acequia de Sangonera.

Casales de molinos que abastecían a las comunidades campesinas que los gestionaban, aunque otros estuvieron en manos de particulares, como los que aparecen en alquerías regadas por la acequia de Alquibla en Alcantarilla, Petrener y Aljucer, que se denominaron con gentilicios, como los molinos que cerca de Alcantarilla tuvieron los Banu Waddad, Aben Huadad o Benihuadach, un linaje con importante arraigo y poder territorial en Murcia desde el siglo IX, o los molinos de Benabia (pertenecientes al linaje Bani al-Nabiha), en la zona sur, cerca de la actual Puebla de Soto ${ }^{25}$. También en Alcantarilla aparecen algunos molinos cuyos nombres quedan por estudiar, tales como los que tomaban agua de la acequia de Almuztad, los especificados como molinos de Farquin $^{26}$ o los que abastecía la acequia de Daliof próximos a los molinos de $A b e u z d a^{27}$.

Mientras que en la zona del sureste del regadío se localizan molinos en las acequias de Benetúcer y Benifiar y también los situados en el camino que iba desde

24. Martínez Martínez 2014, pp. 17-30; 2013b, pp. 283-318.

25. Estos molinos los concedió en 1277 al monasterio de Santa María la Real de Murcia, entre otros bienes, para que los monjes cistercienses rogaran por la vida del monarca y por su alma tras su muerte: Torres Fontes 2008, p. 303.

26. ¿Podría ser una errata de transcripción y referirse a Tarquín, que significaría que el molino toma el nombre de las tierras que por su abundancia de agua se sedimenta el tarquín que lleva y fertiliza de forma natural del suelo?

27. Topónimos registrados en 1251 y 1252, cuando el todavía infante don Alfonso, al ceder a la orden de Alcántara la aldea de Alcantarilla le concedía - por poco tiempo- señalaba las acequias que alimentaban los molinos en esa fértil zona de huerta y que habían sido propiedad de algunos musulmanes expropiados tras la conquista: Torres Fontes 2008, pp. 28 y 32. 
Murcia a Cartagena. Pero el equipamiento molinar más significativo del regadío murciano fue el compuesto por los molinos de Meccen en el sector sur-suroeste de la huerta, cuyo topónimo (al-Majzen, Al-Majzan) señalaría la existencia de un almacén, granero o silo comunitario para guardar y conservar el grano de los habitantes de dicha alquería. Molinos andalusíes que se fortificaban con torres ${ }^{28}$ como las adosadas a las casas rurales o las dedicadas a palomares, referentes paisajísticos del poblamiento rural y estímulo para la colonización-repoblación del territorio durante y después del dominio islámico.

Un paisaje molinar que definía el poblamiento rural y se adentraba en la medina, donde en la alcazaba se erigían los molinos de Darxarife o Casa del Príncipe, derribados en 1777, que tomaban agua directamente del río ${ }^{29}$, o el casal que en la zona norte del arrabal de la Arrixaca perteneció a Ibn Hamete, abastecido por la acequia de Caravija y expropiado por Alfonso X, junto al que Sancho IV, en 1282, autorizaba la construcción de un molino trapero o batán y cinco años después otro casal para el concejo ${ }^{30}$. Un legado molinar mursí que el dominio castellano extendió y que manifiesta las transformaciones socioeconómicas resultantes del cambio cultural.

Reparto de tierras, agua, cultivos, árboles, palomares, casas, mezquitas, torres, molinos, norias, artefactos hidráulicos, alfares, norias y todo tipo de bienes andalusíes que se trasvasaron a repobladores y señores cristianos y a las instituciones del nuevo poder castellano: el Concejo y la Iglesia. Y molinos de agua que coexistieron en la Murcia islámica con artilugios más rudimentarios (aceñas de sangre, algaidones, alhataras y cigoñales) usados en el riego de tierras con dificultades de acceso al agua, que formaron parte del legado molinar mursí, que proseguiría su expansión en la Baja Edad Media castellana con la construcción de otros nuevos y con los que los "señores de molinos" incrementaban sus rentas procedentes de la agricultura, la ganadería y la protoindustrialización.

Fue, por tanto, desde el dominio andalusí cuando se colonizaba sin ruptura la vega media de Segura, sobre todo a partir de la fundación de la medina en el siglo IX, y se desarrollaba un paisaje idealizado por los poetas árabes: paisaje literario, mito paradisíaco de la tierra, fruto de la nostalgia o la exageración. La organización del poblamiento en el regadío se desplegaba en torno a la medina, donde las comunidades campesinas clánico-familiares habitaban las dispersas al-

28. Un elemento defensivo que continuarían los castellanos: en 1287 Sancho IV autorizaba al concejo de Murcia a construir un casal de molinos con una torre bajo el azud de la acequia de Alquibla: Torres Fontes 1977, pp. 67-68. No se refiere a la acequia mayor de Alquibla sino de un brazal de la acequia mayor de Aljufía que regaba la zona noroeste del regadío y en concreto las tierras meridionales situadas entre la acequia de Bendamé y el camino que se dirigía a Molina Seca (actualmente Molina de Segura).

29. El equipamiento molinar urbano andalusí (aceñas o molinos de rueda vertical) más importante se concentraba en el Alcázar, donde el concejo y otros linajes poseían los denominados "molinos de aquende", frente a los que en la segunda mitad se construían en la margen opuesta o derecha del río conocidos como "molinos de allende" o molinos nuevos, donde hoy se sitúa el Museo Hidráulico, referente del inicio de la expansión molinar castellana (urbana y señorial).

30. Torres Fontes 2008, p. 336. 
querías del entorno, cuyas tierras regaban más de setenta acequias, pero también el secano del campo de Cartagena, con fauna y flora silvo-pastoril, fue explotado por los campesinos que habitaron los rahales y extraían y conservaban el agua mediante pozos artesianos y aljibes.

Escenario paisajístico visual, de olores y sabores, emocional y real, añorado, vivido y trabajado que desde la realidad física registraron prosaicamente los repartidores de tierras: dos realidades textuales diferentes (andalusí y castellana) en contraste, cuya memoria tangible e intangible se ha tratado de recuperar como una seña de la identidad histórica de los murcianos.

\subsection{El legado paisajístico mursí a Castilla}

Cuando tras la firma del pacto de Alcaraz en 1243 los castellanos entraron con el futuro Alfonso X en la Murcia hudí vieron una medina rodeada de un paisaje agrario prácticamente desconocido para ellos: una tierra nutrida por el agua y parcelada por acequias, un aparente laberinto de caminos de agua, de ida y vuelta, de puentes y alquerías, que legaba el largo dominio andalusí a la nueva sociedad cristiana. Pero ese pacto feudovasallático de protectorado político pronto derivó en auténtico dominio tras la represión mudéjar de 1266 y los consiguientes nuevos repartos del regadío entre los repobladores, con la concesión de un fuero a la ciudad y la dependencia de la jurisdicción de la huerta al concejo capitalino, si bien esto no impediría la formación de un concejo rural formado por los propietarios del regadío, con su propia organización interna y cierta autonomía hasta la segunda mitad del siglo XIV.

Los conquistadores, dueños de la ciudad y su tierra, comenzaron a partir de 1266 a establecer el gran cambio cultural que implicaba el reparto de la ciudad, de la huerta y del campo entre los cristianos repobladores -que de mayoritaria procedencia catalana no sumaron en total los 2.000, según se registran en el Libro del Repartimiento: a todas luces una insuficiente repoblación-y la paralela relegación y degradación de los mursíes o mudéjares que no tomaron el camino del exilio. Los antiguos pobladores musulmanes habían organizado y explotado con el desarrollo del sistema hidráulico un espacio económico fragmentado en pequeñas propiedades con derecho a agua de riego, cuya tradición se mantuvo bajo el poder castellano y sobre la que se establecerían algunas modificaciones en los siglos XIV y XV.

Un paisaje de agua contenido en el Libro del Repartimiento que, articulado por el eje fluvial a través de acequias y azarbes, ramblas, presas, puentes y puentecillos, molinos hidráulicos y artilugios de riego tradicional, casas, mezquitas, palomares y torres, balsas y abrevaderos, zonas de pesca, arbolado y cultivos, caminos y sendas, dehesas y pastos, era intervenido por los nuevos dueños del territorio que sustituían a las comunidades campesinas mursíes, relegadas y marginadas con los rumíes (mozárabes arabizados), conversos y la base social cristiana menos favorecida, que se concentraba en el suroeste (Almunia y 
Arboleja $)^{31}$ o en otras zonas con escasas posibilidades de riego y que se regaban con artilugios rudimentarios.

A finales del siglo XIII el regadío mursí había sido repartido entre los cristianos, y en 1293 Sancho IV daba el golpe de gracia cuando a petición del concejo de Murcia prohibió que los musulmanes ni los judíos pudiesen tener propiedades en la huerta, salvo que fuese en pago de una deuda:

Otrosi, a los que me pidieron que los jodios et los moros non ouiesen los eredamientos de los christianos por conpra nin por entrega nin en otra manera... Tenemos por bien que los heredamientos que auian fasta agora que los vendan del dia que este ordenamiento es fecho fasa vn anno, et que los vendan a quien quisiere en tal manera que los compradores sean a tales que lo puedar auer con fuero et con derecho, et que daqui adelante que los non puedan conprar nin auer saluo ende quando el eredamiento del su deudor se ouiere a vender seyendo apregonado segun fuero, si non fallaren quien lo conpre que lo tome él en entrega de su deuda... ${ }^{32}$

El paisaje hidráulico heredado se integraba en un todo paisajístico complementario: la medina y la huerta, separadas por las murallas urbanas. La medina abrazada por el rio que bañaba la muralla por el sur y sureste -donde un meandro rodeaba Axerca, cristianizado después como arrabal de san Juan-, mientras que en la zona de la medina norte circulaba paralelamente el agua de las acequias. Y también un todo jurisdiccional desde que Alfonso X le concediera en 1266 un fuero a la ciudad: la huerta dependería en última instancia de las autoridades municipales; $\mathrm{y}$, asimismo, un todo económico que conectaba la producción agraria con las manufacturas y el comercio local y regional (mercado semanal del jueves y feria de san Miguel en septiembre).

El sistema de riego andalusí configurado desde el Azud Mayor y las dos acequias mayores con sus correspondientes azarbes permaneció prácticamente inalterado hasta el siglo $\mathrm{XV}$, no así las estructuras de poblamiento de alquerías, rahales y reales que habían cohesionado a la sociedad rural mursí. Más de 70 alquerías y 72 acequias se contabilizan en los repartos de tierras efectuados en la segunda mitad del siglo XIII. La insuficiente repoblación cristiana y el exilio musulmán de 1266 produjeron el abandono de tierras yermas y el crecimiento de la superficie anegada por el agua. Los almarjales -representados en el regadío murciano con el extenso de Monteagudo, que limitaba con Orihuela- fueron, no obstante, espacios productivos que formaron parte del paisaje agropecuario del regadío levantino bajomedieval en las zonas del Bajo Segura ${ }^{33}$, explotados por la sociedad cristiana

31. Martínez Martínez 2000, p. 66.

32. Torres Fontes 1977 , p. 140.

33. Parra Villaescusa 2015, pp. 69-70. Se circunscribe el estudio a la vega baja de Orihuela, cuyo análisis está relacionado con el limítrofe almarjal murciano de Monteagudo y las tierras que delimitaban la frontera castellana de Orihuela en la Puerta de Murcia y la partida de Moquita. Acerca de los problemas de desecación de este sector fronterizo y del azarbe de Monteagudo en el siglo XV y principios del XVI: Martínez Carrillo 1997, pp. 151-159; Martínez Martínez 2013a, pp. 95-96. 
dadas sus posibilidades de riqueza (cultivo de arroz, ajonjolí, cáñamo, pesca de anguilas, pasto, caza, etcétera).

Consecuencia del fracaso repoblador, de la despoblación del territorio y sus efectos sobre el regadío, resulta ejemplar que en 1308 Fernando IV acensara a Juan de la Peraleja 1.000 tahúllas en el almarjal de Monteagudo ${ }^{34}$ para su explotación. El monarca pretendía paliar el fracaso repoblador que había originado que muchas de las tierras quedaran sin cultivo, despobladas y anegadas: un paisaje desolador del regadío y el secano que se trataba de paliar ordenando nuevos repartos sobre las tierras que habían sido abandonadas por sus propietarios:

Sepades que me dixeron que Pero Martinez Calviello et Berenguel de Pujalte, vuestros mandaderos, me dixeron que en vuestro termino, asy en los alvares como en los almarjales de Monteagudo et en otros lugares del adelantamiento, a heredamientos vagados que son yermos, porque los han lexado los señores dellos por su voluntad, et que es fincado de algunos que finaron sin manda et sin herederos, et otrosy, porque los señores dellos se son ydos a morar a otras partes et no fazen y ninguna vecindad, et que si tales heredamientos fuesen dados et partidos a vos, que seria mio servicio et pro et poblamiento del lugar. Et yo tengolo por bien, porque vos mando y a, que dos o tres omes buenos de vos que los dedes et partades luego entre vos en aquella guisa que sea mas mio servicio et pro vuestra ${ }^{35}$.

Especialmente afectadas fueron las tierras de los sectores más bajos de la huerta (en las márgenes del Segura tras su paso por la ciudad) y más fácilmente inundables, donde además evacuaban acequias y azarbes, cuya costosa financiación de drenaje obligaba a aprovechar sus recursos naturales y los de las tierras próximas al área pantanosa para mantenerlas productivas como zonas de pasto, de cultivo de arroz, de pesqueras, caza, junco y carrizo, sosa y plantas barrilleras o grana en beneficio de la élite murciana, como el señor Carlos de Guevara a finales del siglo XV.

El regadío mursí se había reducido tras el dominio castellano a unas $4.000 \mathrm{Ha}$, cuya recuperación fue lenta (con fases de estabilidad, retroceso y crisis) y no se hizo visible hasta finales de la Edad Media, cuando la expansión agraria con el nuevo cultivo de la morera, la política hidráulica de los Reyes Católicos, basada en una compleja tarea ordenancista en el regadío, la desecación de almarjales para la producción de cereal y la desaparición de la frontera con el emirato nazarí coadyuvaron en alcanzar después de más de dos siglos en torno a las 6.000 Ha. de riego, similar a la superficie regada por los musulmanes murcianos ${ }^{36}$. Con el dominio castellano se redujo el área de riego por la inundación de las tierras más bajas y lo costoso de su drenaje, se debilitaba el gran minifundio andalusí con el proceso de

34. Torres Fontes 1980, p. 88.

35. Ibid., p. 88.

36. Acerca de la evolución del regadío bajomedieval castellano véase Torres Fontes 1975; García Díaz 1990; Martínez Carrillo 1997; Menjot 2008, pp. 71-93; Martínez Martínez 2013a, pp. 43-78. Menjot 2008 no considera que el regadío se redujese tras la conquista cristiana, pp. 81 y 84 
señorialización iniciado tras el dominio castellano ${ }^{37}$-bien consolidado en el siglo $\mathrm{XV}$ - y se desarrollaba la ganadería - por la demanda comercial de lana y la menor mano de obra que necesitaba: factores que originaron constantes conflictos por la defensa del regadío. El condicionamiento de la frontera nazarí (que atenazó el crecimiento poblacional) durante dos siglos y medio (1243-1492) fue una rémora para el desarrollo de la huerta, pero no el único.

La política municipal -pese a la expansión de la ganadería, caracterizadora de una economía de frontera y de una tierra con escasez de pobladores- mantuvo la defensa de la huerta, el mayor bien de la ciudad en palabras del concejo. Para protegerla desde Alfonso X hasta los Reyes Católicos ${ }^{38}$ se dictaminaron todo un conjunto de ordenanzas, cuyo incumplimiento era notorio. Durante el bajomedievo castellano las transformaciones del paisaje agropecuario ${ }^{39}$ acusaron los viejos problemas de la administración del agua que se agravaron además con otros nuevos. Legislar para defender la huerta de los daños que el desarrollo de la ganadería local (y trashumante) ${ }^{40}$ causaba en las zonas de cultivo, o de los robos de agua y de frutos y talas de arbolado, del aumento de las zonas anegadas o almarjales, de la competencia por el agua que usaban los señores de los molinos fue una constante tarea que resultó poco eficaz porque, además, se potenciaba por las corruptelas de las autoridades concejiles y huertanas.

A estas causas negativas para la recuperación del regadío, se sumaba el propio poder del agua ${ }^{41}$ como elemento de la naturaleza que alternaba temporales -que inundaban y destruían la infraestructura de riego, las viviendas y las cosechas y causaba la muerte de personas y animales- con sequías que devastaban cultivos y pastos y provocaban hambres y carestías, especulación y comercio clandestino y protestas sociales agravadas por la presión fiscal.

La obtención de agua era la clave del poder económico de una minoría social oligárquica y eclesiástica que acumulaba riqueza derivada de la señorialización del regadío, la privatización de tierras comunales y dehesas para el ganado, la po-

37. Iniciado, aunque limitado, por Alfonso X con la concesión de grandes propiedades (no necesariamente compactas) en la huerta, como muestra la concesión en 1272 a don Hugo de Anglerola de un extenso lote territorial valorado en 101 alfabas, situado en la alquería de "Aljouff", en la mejor zona de la huerta regada por la acequia mayor de Aljufía, formado por las propiedades que habían pertenecido a 31 mursíes, o la gran propiedad que había pertenecido al arráez de Málaga, valorada en 900 alfabas, que el monarca concedía en 1272 al monasterio de Santa María la Real de Murcia: Torres Fontes 2008, pp. 267 y 313; o las 650 tahúllas que en 1275 concedía al obispo y cabildo, valoradas en 300 alfabas, en las alquerías de Rabat Algidit y Albadel, en el suroeste: Torres Fontes 1969, pp. 5860; también la alquería de Alcantarilla que en 1283 Alfonso X concedió al concejo murciano: Torres Fontes 2008, p. 341, aunque a principios del siglo XIV la trasvasó a la Iglesia. Otros ejemplos compilados por Martínez Martínez 2013 a, pp. 35-38, proceden de la variada documentación editada por Torres Fontes: la alquería de Fidaxat (en la Actual Arboleja) compuesta por las tierras expropiadas a 34 musulmanes la traspasaba en 1286 Sancho IV a su copero Fernán Núñez; asimismo, los varios reales cuajados de frutales (higueras, perales, parras, etétera) donados al comendador santiaguista de Aledo Juan Martín en 1293, etcétera.

38. Martínez Martínez y Hernández Martínez 2015; Martínez Martínez 2011.

39. Menjot 2008, pp. 84-122.

40. Menjot 2008, pp. 122-130; Martínez Carrillo 1982.

41. Martínez Martínez 2013a, pp. 79-90. 
sesión de molinos y rentas hidráulicas acumuladas ${ }^{42}$. La guerra contra el emirato nazarí absorbió hombres y dinero vía reclutamiento militar y fiscal e incidió sobre estos viejos y nuevos problemas del regadío que heredaría, desaparecida la frontera murciano-granadina, la Edad Moderna.

El paisaje del agua heredado fue conflictivo desde el inicio del dominio castellano en Murcia por la apropiación de agua, como confirman algunos de los enfrentamientos bien documentados, como los derivados del complejo reparto de agua de riego, el largo pleito mantenido entre la Iglesia e Iñigo Jiménez de Lorca y sus herederos (1285-1304) por la huerta, la noria, y la viña que este tenía junto al Alcázar musulmán, y la reparación de la presa urbana que potenciaba la energía de los molinos que estos propietarios tenían instalados en el tramo del alcázar ${ }^{43}$, o el que mantuvieron dieciocho eclesiásticos con una compañía de cuatro caballeros por los molinos de cereal situados entre el Alcázar musulmán y el nuevo arrabal cristiano de san Juan, entre otros muchos que jalonan el bajomedievo.

La avaricia por el agua para riego o como fuerza energética, obligaba a Alfonso $\mathrm{X}$ a que se distribuyera proporcionalmente siguiendo la tradición islámica de repartirla "comunalmente", por días y por tiempos, según la superficie de riego de cada propietario ${ }^{44}$. La proximidad de la huerta de Orihuela (incluida en época islámica en la cora de Tudmir y en Castilla desde mediados del siglo XIII hasta 1304) propiciaba bastantes problemas entre murcianos y oriolanos, derivados del desagüe de las aguas murcianas en la vega baja, pues ambos regadíos compartían desde el tratado de Torrellas en 1304 un mismo sistema hidráulico pero situado en fronteras políticas diferentes (Murcia en Castilla y Orihuela en Aragón). Las quejas fueron frecuentes por diversas razones: por ejemplo, cuando en $1271 \mathrm{Al}$ fonso X prohibía a los murcianos que lavasen y cociesen lino y cáñamo en el río porque el agua de riego llegaba contaminada y producía "daño y enfermedades" a los oriolanos ${ }^{45}$.

42. Por ejemplo, en 1261, el adelantado mayor de Castilla don Pedro Guzmán cedía al monasterio de Santa María de Alcocer, fundado por su hermana doña Mayor Guillem, 50 mrs. de oro procedente de la renta de los molinos que tenía en Murcia: Torres Fontes 2008, p. 119.

43. Torres Fontes 1969, pp. 81-82; La Iglesia acumulaba la propiedad molinar, bien por concesión regia (sobre todo con Sancho IV, que le concedió el cobro de censos por tierras, molinos, hornos y tiendas y el monopolio molinar en la zona del Alcázar), bien por ventas de particulares como la que el matrimonio Jaime Morella y doña Menga efectuaba en 1288 para pagar una deuda de $550 \mathrm{mrs}$. con los molinos de Benifandet instalados la zona norte del río, bien por compra de la Iglesia a competidores de energía hidráulica, como Íñigo Jiménez de Lorca y el consiguiente pleito documentado en época de Sancho IV: Torres Fontes 1977, pp. 28, 29, 38, 40, 50, 80, 96, 131 y 133. En 1304 Jaime II concedía a Pedro Jiménez de Lorca unos molinos junto al Alcázar, posiblemente los que, en 1290, Íñigo Jiménez de Lorca ¿su padre? vendió a la Iglesia: Torres Fontes 1969, pp. 87-90 y 93.

44. En 1277 Alfonso X ordenaba: "por fazer bien et merçed al conçeio de Murcia et por sacar contienda entrellos, tengo por bien et mando que partan el agua entre si comunalmientre, asi que cada uno aya su parte segunt ouiere tierra et sepa el dia en que la ha de tomar". En Lorca, los señores a quienes se les habían concedido donadíos (grandes propiedades) acaparaban el agua para sus tierras y "no la dexan salir de sus huertas afuera pora pan nin pora otra cosa ninguna": Torres Fontes 2008, pp. 191, 300 .

45. Torres Fontes 2008, pp. 212-213. 
La huerta de Murcia entró desde mediados del siglo XIX en un proceso de degradación y profundos cambios en el ecosistema que fueron contundentes a partir de los años ochenta del siglo XX por el desarrollismo urbanístico y especulativo sobre ella operado. Un cambio que hoy hace casi irreconocible ese paisaje histórico -y del huertano un elemento del folclore- que aún perdura controlado por la institución de raíz islámica derivada del sahib saqib o señor de la acequia vinculada a la cristiana-romanista de los hombres buenos para administrar la justicia en el regadío. Desde esa vinculación establecida por Alfonso X evolucionaría el Consejo de Hombres Buenos, que institucionalizado como tribunal del regadío fue declarado por la UNESCO patrimonio inmaterial de la Humanidad en $2009^{46}$. Y junto a esta loable tradición administrativa judicial y privativa de la huerta que representa el Consejo de Hombres Buenos, existe una mayor conciencia social de la necesidad de su conservación y protección, tal como actualmente el ayuntamiento de Murcia y algunas asociaciones realizan.

\section{LOS NOMBRES DEL PAISAJE}

El paisaje de la huerta se fue identificando con nombres de lugares referidos a personas, elementos naturales y de hábitat de reconocimiento colectivo que perduraban en el tiempo. Nombres documentados en las fuentes árabes y castellanas que remiten a una visualización mental del paisaje. Historiadores, geógrafos y poetas árabes fijaron con la toponimia las imágenes del paisaje mursí que a su vez registró el Libro del Repartimiento y los documentos conservados para la segunda mitad del siglo XIII. Nombres de un paisaje heredado que anotaron los repartidores y escribanos cristianos con la colaboración de los acimenos moros que lo habitaron.

Los nombres de la huerta encierran su pasado, porque, como bien indica Pocklington la toponimia murciana es un testimonio vivo de su historia ${ }^{47}$. La etimología de los nombres del paisaje estudiada por el arabista así lo demuestra, y muchos de ellos perduran en los actuales núcleos de población. Entre las fuentes árabes la $Q a$ sida Maqsura, escrita a mediados del siglo XIII por el poeta de origen murciano Hazim al-Qartayanni establecido en la corte tunecina, incluye una rica toponimia del campo y el regadío murcianos, así como su localización. En un reciente estudio, el citado autor, puntualiza y localiza la toponimia correspondiente a la huerta de Murcia que el exquisito poeta cartagenero registraba en 107 versos en los que cantaba sus encantos paisajísticos, propiciatorios del placer, la contemplación de la belleza, el paseo, el esparcimiento y la galantería.

El recorrido del paisaje poetizado desde la memoria vívida de al-Qartayanni seguía una orientación de este a oeste en las zonas norte y sur del regadío. Y en aquel paisaje recordado líricamente con nostalgia destacaba el poeta la siguiente toponimia: Bani Isam (El Raal), al-Qantara al Bayda (el puente blanco), al-Zanaqat

46. Martínez Martínez (en prensa); 2013a, pp.113-118; 2005, pp. 21-67.

47. Pocklington 2013. 
(La Arboleja), al-Tay (Beniscornia), las colinas de Kudyat al-Rasid (¿Cabezo de Torres?), Tel Alquibir (Era Alta), Hisn al-Faray (castillo de Larache), Montaqud (Monteagudo), Qars Ibn Sa`d (El Castillejo), al-Maruy (almarjales que rodeaban Monteagudo), al-Suhayriy (La Albatalía), Ayallu (Verdolay), Bani Su'ud (Santiago el Mayor), al-Yusayr (Aljucer) al-Furss y Sikka (Rincón de Seca), al-Bard, al-Junays y al-Tall (Era Alta), al-Sudd (Azud o actual Contraparada), Munyab y Muntad (Alquerías), al-Wustà (acequia de Alguazas) y al-Yaqutatay y Nubla (El Palmar y Sangonera), los cuales comparaba con lugares idílicos de la antigua Arabia y del Medio Oriente ${ }^{48}$. Lugares periurbanos, acequias y parajes fluviales redivivos de la huerta murciano-oriolana cuya perdurable toponimia nos retrotrae con añoranza a un paisaje prácticamente perdido. Nombres evocadores localizados en lugares o sectores concretos que permiten "imaginar" aquel paisaje de tierra, agua y vegetación que tanta fama dio al regadío mursí. Rincones de tierra poblada aprovechando los meandros del río y la tierra colmada con sus limos. El valioso lenguaje que nombra este paisaje constituye un útil código para descifrar la evolución de la huerta murciana bajo dominio islámico y en la transición hacia su integración en la Corona de Castilla: Algezares (cantera de yeso), Tel Alquibir (colina grande), Melaztay (residencia de un grupo familiar), La Alberca (balsa), Mayayo (nombre de un repoblador cristiano). Los nombres latinos o preislámicos registrados en los textos del Repartimiento del siglo XIII, ¿indican un poblamiento parcial o continuado desde tiempos romanos antes del siglo VIII? o ¿también podrían señalar asentamientos de mozárabes atraídos por la fundación de Madinat Mursiya a partir del siglo IX?

Según lo analizado en los estudios toponímicos hubo un poblamiento rural preislámico parcial e interrumpido que se ampliaría con la colonización andalusí de la vega media a partir de la fundación de la medina en el siglo IX, pero que antes y después de este siglo y durante los periodos taifales de los siglos XI y XII fue tierra de acogida de grupos de mozárabes y neomusulmanes. Otros topónimos aún quedan por estudiar, tales como Almuztad, Abeuzda, Farquin ${ }^{49}$ o Daliof, que dejo en manos de arabistas. Se trata de cuatro registrados en 1251 y 1252 , cuando el todavía infante don Alfonso, al ceder a la orden de Alcántara la aldea de Alcantarilla, le concedía - por poco tiempo- también los molinos que en ella tomaban agua de la acequia de Almuztad y los de la acequia de Daliof, junto al otro equipamiento instalado sobre el río conocido como molinos de $A b e u z d a^{50}$, posiblemente el nombre del antiguo propietario.

Sobre un espacio natural se creó y desarrolló un paisaje humanizado intervenido por muchas generaciones de personas, cuya identidad se ha podido rescatar para culturas y sociedades antagónicas, compuestas por clanes, familias e individuos, a través de la antroponimia y la toponimia. Paisaje reconstruido mediante las fuentes escritas que nos devuelven al presente de un pasado medieval andalusí-castellano.

48. Pocklington 2016.

49. ¿Podría ser una errata de transcripción y referirse a Tarquín, que significaría que el molino toma el nombre de las tierras que por su abundancia de agua sedimenta el tarquín o fertilizante natural del suelo?

50. Torres Fontes 2008, pp. 28 y 32. 


\section{CONSIDERACIONES GENERALES}

El reconstruido paisaje del regadío murciano en su etapa de transición del dominio islámico al castellano durante el siglo XIII es la manifestación de dos sociedades contrastadas que lo habitaron y aprovecharon. Y aunque la nueva sociedad cristiana feudalizada que sustituyó a la andalusí desde mediados del siglo XIII intentó conservar el legado del regadío, la insuficiente mano de obra, el desarrollo de la ganadería, las situación de la ciudad y de su territorio en la frontera con el emirato nazarí, la privatización y señorialización de la huerta con pueblas y dehesas, los encontrados intereses económicos de las oligarquías locales por el agua y los pastos y las corruptelas de las autoridades dificultaron ostensiblemente su mantenimiento, si bien el concejo y la monarquía abogaron por su defensa.

Las funciones militares de la nueva sociedad feudalizada eran prioritarias para la defensa de las personas, cultivos y bienes de las amenazas y ofensivas provenientes del otro lado de la frontera nazarí o para movilizarse en cabalgadas y acciones contra el cercano enemigo granadino, lo que explica que se impusiese desde mediados del siglo XIII un paisaje de frontera más inseguro en la huerta, desamparada de las murallas de la ciudad, sobre el que redundaban los efectos de una población siempre insuficiente. Sociedad amenazada incontroladamente por el poder de la naturaleza y sus nefastos ciclos de sequías e inundaciones que empobrecían la vida de la gente. El desarrollo de la ganadería murciana se impuso en este paisaje de frontera, aunque la protección de la huerta fue desde mediados del siglo XIII un objetivo constante de la política regia y municipal.

Un paisaje natural milenario reconvertido en un todo material e inmaterial que todavía en esencia identifica a las gentes de Valencia, Alicante y Murcia porque configura uno de sus fundamentos culturales. Paisaje y cultura del regadío que engloba formas de vida, costumbres, técnicas, habla, toponimia y valores, consecuencia del histórico trabajo de las sociedades sobre el paisaje. La conquista castellana de mediados del siglo XIII sobre el emirato mursí produjo un brusco cambio cultural que integraba definitivamente el reino de Murcia en la civilización europea, cuando se iniciaban algunas de las transformaciones que fundamentan la identidad regional murciana, sin la renuncia de las importantes aportaciones, influencias y tradiciones andalusíes.

\section{BiBLIOGRAFÍA CITADA}

Belando y Menéndez, José (1878), El río Segura y la Huerta de Murcia, Murcia. Calvo García-Tornel, Francisco (1982), Continuidad y cambio en la huerta de Murcia, Murcia.

Calvo García-Tornel, Francisco (1989), “Aproximación a la huerta musulmana”, en Murcia musulmana, pp. 385-393. 
Calvo García-Tornel, Francisco y Olivares, Pedro (1967-1968), "La huerta de Murcia en los siglos XII y XIII", en Anales de la Universidad de Murcia. Filosofía y Letras, XXVI, núm. 4, pp. 423-432.

Carmona González, Alfonso y Pocklington, Robert (2008), Agua e irrigación en la Murcia árabe, Murcia.

Díaz Cassou, Pedro (1887), La Huerta de Murcia, su topografía, geología y climatología; descripción de sus sistemas de riego y saneamiento, Madrid.

Eiroa Rodríguez, Jorge A. (2010a), “Arqueología de los espacios agrarios andalusíes en el sureste peninsular: nuevas perspectivas desde la periferia", en Por una arqueología agraria: perspectivas de investigación sobre espacios de cultivo en las sociedades medievales hispánicas, Oxford, pp. 107-122.

Eiroa Rodríguez Jorge A. (2010b), "Paisajes agrícolas en el sureste de al-Andalus a partir de las fuentes árabes”, en M. Jiménez Puertas y L. Mattei (eds.). El paisaje y su dimensión arqueológica. Estudios sobre el Sur de la Península Ibérica en la Edad Media, Granada, pp. 57-75.

Eiroa Rodríguez, Jorge A. (2011), "El cambio agrícola tras el 711", en 711. Arqueología e Historia entre dos mundos, vol. II, núm. 15, Alcalá de Henares.

Franco Sánchez, Francisco (2014), "Noticias de ataques y destrucciones en Orihuela durante el periodo andalusí (ss. VIII-XIII)", en Orihuela. Arqueología y Museo. Museos Municipales en el MARQ, Alicante.

García Blánquez, Luis y Cerdá Mondéjar, Leticia (2007), "Estructuras hidráulicas medievales: tres aceñas y un tablacho en las acequias de Churra la Vieja y Alfatego. Senda de Granada (Murcia)", en Revista Murciana de Antropología, 14, pp. 343-362.

García Díaz, Isabel (1990), La huerta de Murcia en el siglo XIV, Murcia.

Glick, Thomas F. (2007), Paisajes de conquista. Cambio cultural y geográfico en la España Medieval, Valencia.

Hérin, Robert (1980), Les <huertas > de Murcie. Les hommes, la terre et l'eau dans L'Espagne aride, Aix-en-Provence.

López Campuzano, Manuel (2002), "Los acueductos de las acequias Alquibla, El Turbedal y La Dava (Alcantarilla): datos arqueológicos sobre la evolución del sistema de regadío rural de la huerta de Murcia durante la Alta y Baja Edad Media”, en Memorias de Arqueología, 10, pp. 635-655.

Malpica Cuello, Antonio (2014), Las últimas tierras de al-Ándalus. Paisaje y poblamiento del reino nazari de Granada, Granada.

Mancha, Rafael de (2003, ed. facsímil de 1836), Memoria sobre la población y los riegos de la Huerta de Murcia, Murcia.

Manzano Martínez, José (1993), “Toponimia gentilicia y antroponimia musulmanes en la huerta de Murcia”, en Verdolay, 5, pp. 201-217.

Manzano Martínez, José (1999a), “Aproximación a la estructura de la propiedad musulmana de la tierra en la huerta de Murcia”, (siglo XIII), en Castrum, 5, pp. 61-75. 
Manzano Martínez, José (1999b), “Aproximación a la problemática histórica de un espacio hidráulico: la huerta de Murcia”, en Memorias de Arqueología, 9, pp. 489-507.

Martínez Carrillo, Ma de los Llanos (1982), "La ganadería lanar y las ordenanzas de ganaderos murcianos de 1383”, en Miscelánea Medieval Murciana, 9, pp. 119-152.

Martínez Carrillo, $\mathrm{M}^{\mathrm{a}}$ de los Llanos (1997), Los paisajes fluviales y sus hombres en la Baja Edad Media. El discurrir del Segura, Murcia.

Martínez Martínez, María (2000), Las mujeres en la organización de una sociedad de frontera. La etapa colonizadora-repobladora de Murcia, 1266-1272, Murcia.

Martínez Martínez, María (2005), "Vigencia de una institución medieval: el Consejo de Hombres Buenos de Murcia", Mvrgetana, 112, pp. 21-67.

Martínez Martínez, María (2010), "El paisaje del agua en la Murcia árabe (siglos IX-XIII), en Las noches de las tres culturas, Murcia, pp. 65-74.

Martínez Martínez, María (2011, 2ª ed.), Unas ordenanzas inéditas en el reinado de los Reyes Católicos, Murcia.

Martínez Martínez, María (2012), “ $<$ Las que se fueron y las que vinieron>: musulmanas y cristianas en Murcia (siglo XIII)", en Impulsando la historia desde la historia de las mujeres. La estela de Cristina Segura, Universidad de Huelva, pp. 181-187.

Martínez Martínez, María (2013a, 2a ed.), La cultura del agua del agua en la Murcia medieval (siglos $I X-X V)$, Murcia.

Martínez Martínez, María (2013b), "Molinos de agua: Los orígenes medievales del Museo Hidráulico de Murcia", en Estudios sobre Patrimonio, Cultura y Ciencias Medievales, 15, pp. 283-318.

Martínez Martínez, María (2014), “Molinos de Allende”. Antecedentes medievales del Museo Hidráulico de Murcia, Murcia, pp. 17-30.

Martínez Martínez, María (2015), La Murcia andalusí (711-1243). Vida cotidiana, Helsinki.

Martínez Martínez, María (en prensa), "Los orígenes del Consejo de Hombres Buenos de Murcia en el siglo XIII: Revisión y nueva teoría”, en 750 Centenario del fuero de Murcia, Ayuntamiento de Murcia.

Martínez Martínez, María y Hernández Martínez, Pedro (2015), “Las leyes del regadío murciano: conflictividad social y codificación (1479-1503), Medievalismo, 25, 315-355.

Menjot, Denis (2008), Murcia. Ciudad fronteriza en la Castilla bajomedieval, Murcia, pp. 71-93.

Parra Villaescusa, Miriam (2015), “<Aguas peligrosas $>$-Aguas aprovechables: Concepción ideológica y realidad productiva de los marjales. El sur del reino de Valencia (XIV-XV)", en La percepción del agua en la Edad Media, Universidad de Alicante, pp. 39-81.

Perona, José (Ed.) (2002), El Fuero Juzgo Estudios críticos y transcripción, Murcia, pp. 345-346. 
Pocklington, Robert (1990), Estudios toponímicos en torno a los orígenes de Murcia, Murcia.

Pocklington, Robert (2013), La toponimia murciana, testimonio vivo de su Historia, Murcia.

Pocklington, Robert (2016), "La descripción de la Vega de Murcia en la Qasida Maqsura de Hazim al-Qartayanni”, en Estudios sobre Patrimonio, Cultura y Ciencias Medievales, 18, pp. 1021-1050.

Rodríguez Llopis, Miguel (dir.) (2006), Atlas Histórico ilustrado de la Región de Murcia y su antiguo Reino, Murcia.

Torres Fontes, Juan (1969), Documentos del siglo XIII.

Torres Fontes, Juan (1975), El regadio murciano en la primera mitad del siglo $X I V$, Murcia.

Torres Fontes, Juan (1977), Documentos de Sancho IV, Murcia.

Torres Fontes, Juan (1980), Documentos de Fernando IV, Murcia.

Torres Fontes, Juan (1991a), Libro del Repartimiento de las tierras hecho a los pobladores de Murcia, 2 tomos (edición facsímil y transcripción), Murcia.

Torres Fontes, Juan (1991b 2a ed.), Repartimiento de la huerta y el campo de Murcia en el siglo XIII, Murcia.

Torres Fontes, Juan (2008, $2^{\mathrm{a}}$ ed.), Documentos de Alfonso X, Murcia. Murcia.

Torres-Fontes Suárez, Cristina (1996), Viajes de extranjeros por el reino de Murcia, Murcia, t. II.

Trillo San José, Carmen (2003), Agua y paisaje en Granada: una herencia de AlÁndalus, Granada.

Fecha de recepción del artículo: 6 de junio de 2017

Fecha de aceptación y versión final: 27 de septiembre de 2017 
